\title{
Level of Participation of Women in Cowpea Production in Wammako Local Government Area of Sokoto State, Nigeria
}

\author{
Salihu Abdullahi Abubakar ${ }^{1}$, Abdulrahman Bello*2, Binta Muhammed Manga ${ }^{1}$, Maryam Bello Ali ${ }^{1}$, \\ Abdullahi Muazu ${ }^{1}$ and Dalha Magaji ${ }^{1}$
}

${ }^{1}$ Department of Agricultural Technology, Umaru Ali Shinkafi Polytechnic, Nigeria

${ }^{2}$ Department of Veterinary Anatomy, Usmanu Danfodiyo University, Nigeria

*Corresponding author: Abdulrahman Bello, Department of Veterinary Anatomy,

Usmanu Danfodiyo University, Nigeria.

Received Date: January 08, 2020

Published Date: January 24, 2020

\begin{abstract}
The study examined the level of participation of women in cowpea production in Wammako Local Government Area of Sokoto State. The specific objectives were to describe the socio-economic characteristics of women cowpea farmers in the study area, determine the level of income of the women in cowpea production, determine the factors influencing the participation of women in cowpea production and identify the constraints to cowpea production by the women. The study was carried out in Wammako Local Government Area of Sokoto State. Purposive and random sampling techniques were used to select fifty (50) respondents across five villages in three districts of the Local Government Area. Descriptive statistics and regression analysis were the analytical tools used to analyze the data collected. Results of the study showed that the women cowpea farmers were in their later stages of 41-50 years. Majority of them were married (62\%), with household size of about 4-9 people and most of them (72\%) have attempted one form of education or the other however, are small scale farmers with majority (68\%) having farm sizes of 0.1 2.0 hectares. Their primary occupation is trading and farming. Their level of income was found to be low to moderate. Farm size and distance to nearest good road (significant at 1\% and 5\% level respectively) were the factors found to influence women participation in cowpea production. The women cowpea farmers were constrained by pest and diseases, high cost of pesticides and fertilizer, inadequate finance, high cost of labor and poor storage facilities. The study therefore, recommends that government should formulate policies to encourage women farmers, government should also provide incentives specifically to the women farmers like ready market and fixed prices for their outputs, improved cowpea varieties and other inputs should be made readily available and accessible to the women farmers at affordable prices, on time and in adequate quantities, extension service should also be intensified to enhance the women's knowledge on the utilization of improved farming technologies.
\end{abstract}

Keywords: Women; Cowpea, Production; Sokoto; Vigna unguiculate

\section{Introduction}

Cowpea (Vigna unguiculata) is one of the most important staple food crops in sub-Saharan Africa, especially in Nigeria. Cowpea remains one of the cheapest sources of protein in the diet of many Nigerians with protein content of $25 \%$, in addition to its several mineral and vitamins contents [1]. Almost all parts of cowpea are useful for human consumption and as livestock feed making it one of the most important economic crops in the tropics. The crop tolerates drought. It is adapted to the tropics with temperatures between $28^{\circ} \mathrm{C}$ and $30^{\circ} \mathrm{C}$ and rainfall between 500 and $1200 \mathrm{~mm}$ per annum. The crop performs well in a wide variety of soils but performs better on well drained sandy loam to clay loamy soils with $\mathrm{pH}$ between six and seven. Similarly, the bacteria in the root nodules contribute to soil fertility through fixation of nitrogen in the soil and production of organic matter. As such, cowpea is broadly cultivated around the world [2]. Nigeria, with an estimated annual production of 2.17 million tons, is the highest producer of cowpea in the world [3]. The northern region of Nigeria produces about 1.7 million tons from about 4 million hectares, which represents over $60 \%$ of total national production [3]. Despite the increase in production of cowpea in Nigeria over the years as a result of increase in cultivation, the overall productivity is still very low [2]. The problem of this low productivity has been found to result from the use of local varieties of the crop, poor management practices, lack of sufficient inputs, inefficient extension services and lack of or inadequate use of modern technologies [2,4]. Hence, there is 
the need to engage women in all production processes as well as to introduce improved technologies.

Women's contribution to food security in developing countries like Nigeria is well known. Rural women are the mainstay of small-scale agriculture, the farm labor force and day to day family subsistence [5]. About 60-80 percent of food in most developing countries is believed to be cultivated by women; as such they are responsible for half of the world's food production [5]. However, most of women production in developing counties like Nigeria is at subsistence level. This implies that most of what the women produce at most times is being consumed by their household with very little or no produce left for sale. Food insecurity and poverty are serious issues ravaging the female population and in comparison, to men, women have a higher incidence and severity of poverty $[5,6]$. Women performs majority of the farming activities in all phases of agricultural production which include land clearing, land tilling, and planting, weeding, fertilizer/manure application to harvesting, food processing, threshing, winnowing, milling, transportation and marketing as well as the management of livestock [7].Women in Nigeria are therefore saddled with most tasks in agricultural production that should otherwise be done by men but the benefits gained by them are not measurable to the work they performed. Rural women perform the home chores in addition to the number of hours they spent on the farm. Women are engage in family labor in agriculture as well as wage labour and in other income-earning activities; and generate a substantial proportion and sometimes even the entire basic daily food for the family [8].

Agriculture as the main source of food for the people and as a means of livelihood for the most vulnerable citizens in developing countries plays a major role in the development of such countries. As such, raising agricultural productivity is an important policy goal for governments and development agencies and this is central to growth, income distribution, improved food security and poverty alleviation among farmers, and the most among them are the rural women who play vital roles in agricultural production and they are crucial to the overall success of the efforts directed at agricultural development in rural areas. Women farmers mostly grow cowpea to provide food security both to humans and the livestock as well as to serve as an important source of income for them [2]. Despite being the major labour force in small farms and perform most of the farming activities, women are hardly appreciated and have limited access to production resources. They hardly have access to loans, grants and credit facilities. They are hardly reached with improved seeds, fertilizers and other inputs. Men still own land, control women's labour, and make agricultural decisions, extension services are not extended to them, and they are faced with domestic work. It is in view of the above problems that this study seeks to answer the following research questions:

1. What are the socioeconomic characteristics of women farmers in the study area?

2. What is the level of income of women in cowpea production in the study area?
3. What are the factors influencing the participation of women in cowpea production?

4. What are the constraints to cowpea production by women in the study area?

The objective of this study is to examine the level of participation of women farmers in cowpea production in Wammako Local Government Area of Sokoto State. The specific objectives are to: describe the socioeconomic characteristics of the women in the study area, to determine the level of income of the women in cowpea production, to determine the factors influencing the participation of women in cowpea production and to identify constraints to cowpea production by the women in the study area. The study will focus only on women farmers that engage in the production of cowpea. The target of the study will be to draw detail information on the level of the women in cowpea production as well as how their socio-economic characteristics affect their level of participation and the constraints to their production. The study will be carried out in Wamakko Local Government Area of Sokoto State and can be generalized to other areas with similar agro-ecological characteristics. The data collected will be limited mainly to the 2019 season.

\section{Materials and Methods}

\section{Description of the study area}

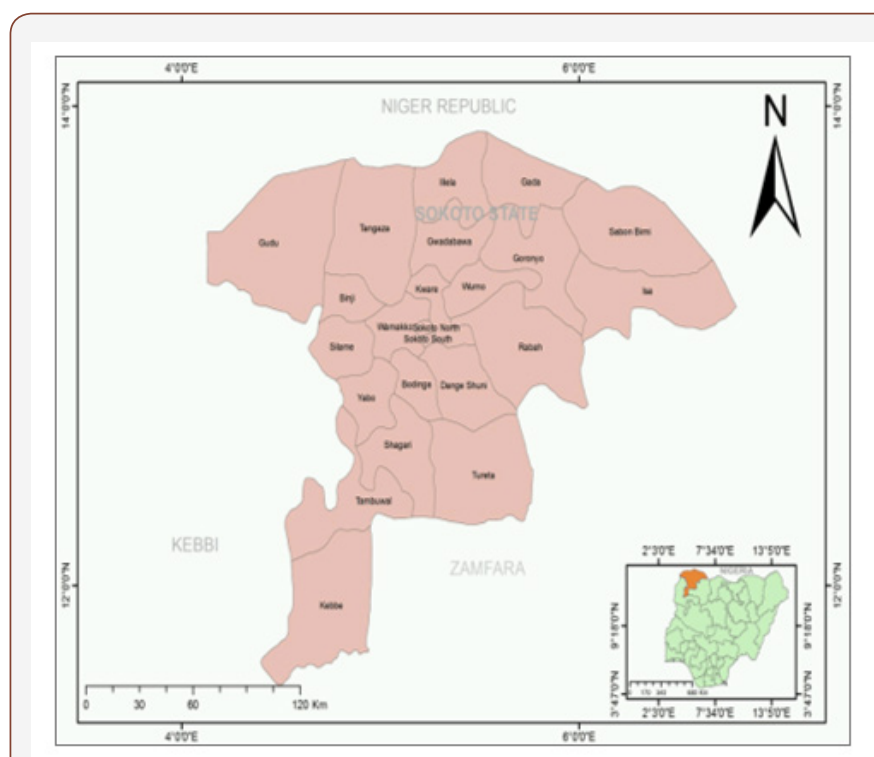

Figure 1: Map of Nigeria Sokoto State Showing the Study Area

Wamakko local government area of Sokoto State is located at latitude $13^{\circ} 2^{\prime} 16^{\prime \prime} \mathrm{N}$ and longitude $5^{\circ} 5^{\prime} 37^{\prime \prime} \mathrm{E}$. It is about 226 meters above the sea level and covers an area of 697 square kilometers with a population of 179,619 [9]. Wamakko shares boundaries with Tangaza and kware Local Government Areas to the East, Binji local government to the North, Sokoto North, Sokoto South and Dange Shuni Local Government Areas to the South and Bodinga and Yabo local government to the West. The local government is mainly populated by Hausa people. It also comprises of four major villages; Kammata, Gwamatse, Kaurankimaba and Kokanicidawa. Ambient temperature ranges from $14^{\circ} \mathrm{C}$ during harmattan period 
of November to January to $38^{\circ} \mathrm{C}$ during the hot season of March to May. The vegetation of the study area is characterized by open grassland interspersed with boa, acacia and locust bean trees. The topography is flat, though there are isolated hills and mountain ranges scattered all over the area. The major occupation of the inhabitants is farming and rearing of animals (Figure 1).

\section{Sampling technique and sample size}

Purposive sampling method was used to select the cowpea farming communities in the study area. Simple random sampling technique was then employed in selecting ten women farmers from 5 villages that engage in cowpea production to give a total of 50 farmers that was used for the study. The villages are Kammata, Fanari (Wammako district) Gumbi, Barkeji (Gumbi district), and Dundaye (Dundaye district).

\section{Data collection}

The data required for this study was collected through the use of a well-structured questionnaire. Information was collected on socioeconomic characteristics of women farmers, level of income of women in cowpea production, and constraints to cowpea production by women farmers.

\section{Data analysis}

The data was analyzed using descriptive and inferential statistics. Descriptive statistics such as frequency, percentage and mean score was used to satisfy objectives i, ii and iv, while objective iii was analyzed using linear regression model. The explicit form of the function is presented as follows:

$Y i=a+B 1 X 1+B 2 X 2+B 3 X 3+B 4 X 4+B 5 X 5+\ldots+B n X n+U$

$\mathrm{Y}=$ Participation of women in cowpea production

X1= Household head

$\mathrm{X} 2=$ farm size

X3= Farm ownership

X4= Membership of Association

$\mathrm{X} 5=$ Number of extension visit

$\mathrm{X} 6=$ Access to credit

X7 = Farm distance to nearest good road

X8 = Village distance to nearest market

X9 = Village distance to nearest good road

$\mathrm{B}=$ Coefficient

$\mathrm{U}=$ Error term

$\mathrm{a}=$ Constant

\section{Result and Discussion}

\section{Socio-economic characteristics of respondents}

Age (years): Table 1 below show that $34 \%$ of the respondent falls between the age range of $41-50$ years, $26 \%$ of the respondent falls between the age range of 50 years and above, $22 \%$ of the respondents were between the age range of $31-40$ years and $18 \%$ of the respondents falls between the age range of 21-30. This suggests that most of the respondents are in their later stages. This implies that farming activities are mostly practiced by elderly people as the youth seeks for white collar jobs (Field Survey, 2019).

Table 1: Socio-economic Characteristics of Women Farmers in Cowpea Production.

\begin{tabular}{|c|c|c|}
\hline \multicolumn{3}{|c|}{ Age } \\
\hline Variable & Frequency & Percentage \\
\hline $21-30$ & 9 & 18 \\
\hline $31-40$ & 11 & 22 \\
\hline $41-50$ & 17 & 34 \\
\hline Above 50 & 13 & 26 \\
\hline \multicolumn{3}{|c|}{ Marital Status } \\
\hline Variable & Frequency & Percentage \\
\hline Single & 2 & 4 \\
\hline Married & 31 & 62 \\
\hline Widowed & 14 & 28 \\
\hline Divorced & 3 & 6 \\
\hline \multicolumn{3}{|c|}{ Occupation } \\
\hline Variable & Frequency & Percentage \\
\hline Farming & 14 & 28 \\
\hline Trade & 22 & 44 \\
\hline Civil service & 13 & 24 \\
\hline Apprenticeship & 2 & 4 \\
\hline \multicolumn{3}{|c|}{ Educational qualification } \\
\hline Variable & Frequency & Percentage \\
\hline No formal education & 14 & 28 \\
\hline Primary & 22 & 44 \\
\hline Secondary & 9 & $18 . .0$ \\
\hline Tertiary & 5 & 10 \\
\hline \multicolumn{3}{|c|}{ Household Size } \\
\hline Variable & Frequency & Percentage \\
\hline 3-Jan & 3 & 6 \\
\hline 6-Apr & 15 & 30 \\
\hline 9-Jul & 13 & 26 \\
\hline 10 persons and above & 19 & 38 \\
\hline \multicolumn{3}{|c|}{ Farming Experience } \\
\hline Variable & Frequency & Percentage \\
\hline 5years and below & 5 & 10 \\
\hline 6-10years & 14 & 28 \\
\hline 11-15years & 12 & 24 \\
\hline 16-20years & 6 & 12 \\
\hline Above 20years & 13 & 26 \\
\hline \multicolumn{3}{|c|}{ Farm Size } \\
\hline Variable & Frequency & Percentage \\
\hline $0.1-2$ & 34 & 68 \\
\hline $2.1-4$ & 15 & 30 \\
\hline 4.1-6 & 0 & 0 \\
\hline $6.1-8$ & 0 & 0 \\
\hline Above 8 & 1 & 2 \\
\hline Total & 50 & 100 \\
\hline
\end{tabular}


Marital status: Table 1 below shows that majority (62\%) of the respondents were married, $28 \%$ of the respondents were widowed, while, $6 \%$ were divorced. This revealed the cultural and religious believes in the study area were a person is regarded as adult if he or she was married and this constituted the productivity of the household (Field Survey, 2019).

Occupation: Table 1 below also shows that $44 \%$ of the respondent's major occupation was trade where as $28 \%, 24 \%$, and $4 \%$ were farmers, civil servants and apprentice respectively. This implies that the women in the study area favors trade than farming (Field Survey, 2019).

Educational qualification: Table 1 below show that $44 \%$ of the respondents had primary education while $28 \%$ of the respondents have no formal education with only $18 \%$ and $10 \%$ of the respondents having secondary and tertiary education respectively. This implies that most of the women farmers engaged in cowpea production highest qualification were primary education. This can have negative influence in the use of improved farming technologies (Field Survey, 2019).

Household size: $38 \%$ of the respondents were found to have household size of above 10 persons, while $30 \%$ of the respondents claimed to have 4-6 persons per household with 26 and 6\% having 7-9 and 1-3 persons per household respectively (Field Survey, 2019).

Farming experience: Table 1 below also shows that $28 \%$ of the respondent have 6-10years farming experience while $26 \%$ have 20 years and above with $24 \%, 12 \%$ and $10 \%$ having between 11-15years, 16-20years and less than 6 years of farming experience respectively. This implies that most women engaged in cowpea production are having lot of experience in farming (Field Survey, 2019).

Farm size: Table 1 below also shows that majority of the respondents $(68 \%)$ have farm size of between 0.1-2.0 whereas $30 \%$ have $2.1-4.0$ with only $2 \%$ of the respondents having above 8 hectares of farmland. This implies that women cowpea farmers in the study area are small scale farmers (Field Survey, 2019) (Table 1).

\section{Perceived level of income}

Table 2: Perceived Level of Income.

\begin{tabular}{|c|c|c|}
\hline Level of Income & Frequency & Percentage \\
\hline Low & 25 & 50 \\
\hline Moderate & 24 & 48 \\
\hline High & 1 & 2 \\
\hline Total & 50 & 100 \\
\hline
\end{tabular}

Table 2 below presents the perceived level of income of women engaged in cowpea production. The results of the finding shows that $50 \%$ of the respondents indicates that their level of income was low, whereas $48 \%$ claimed that their level of income was moderate with the remaining $2 \%$ indicating a high level of income. This suggests that $98 \%$ of the respondents were low to moderate income earners in the study area. The findings corroborate with that of [10-12]. Who reported that women farmers have low level of income due to lack of production inputs (Table 2).

\section{Factors influencing women participation in cowpea production}

Table 3 below present the regression analysis of the factors influencing cowpea production by women farmers. The result indicated a coefficient of multiple determinations (R2) of 0.76 . This means that $76 \%$ variation in the dependent variable (cowpea production) is explained by variation in the explanatory variables included in the model. The result further revealed that farm size and distance to nearest good road were significant at $1 \%$. The positive significance of farm size indicates that the more the farm size the higher the level of participation of women in cowpea production. The negative coefficient of distance to the nearest good road implies that the shorter the distance, the higher the level of participation of women in cowpea production which will results to a higher output (Table 3).

Table 3: Regression Analysis of Factors influencing women Participation in Cowpea.

\begin{tabular}{|c|c|c|c|}
\hline Variable & $\begin{array}{c}\text { Estimated } \\
\text { Coefficient }\end{array}$ & Standard Error & Sig \\
\hline Household Head & -0.338 & 0.347 & $0.336 \mathrm{NS}$ \\
\hline Farm Size & 1.2 & 0.134 & $0.000^{* * *}$ \\
\hline Farm ownership & -0.279 & 0.352 & $0.433 \mathrm{NS}$ \\
\hline $\begin{array}{c}\text { Membership of } \\
\text { Association }\end{array}$ & -0.699 & 0.591 & $0.243 \mathrm{NS}$ \\
\hline $\begin{array}{c}\text { Number of Extension } \\
\text { Visit }\end{array}$ & -0.012 & 0.043 & $0.777 \mathrm{NS}$ \\
\hline $\begin{array}{c}\text { Farm distance to } \\
\text { nearest good road }\end{array}$ & -0.419 & 0.135 & $0.003 * * *$ \\
\hline $\begin{array}{c}\text { Village distance to } \\
\text { nearest market }\end{array}$ & -0.153 & 0.099 & $0.128 \mathrm{NS}$ \\
\hline $\begin{array}{c}\text { Village distance to } \\
\text { nearest good road }\end{array}$ & -0.324 & 0.605 & $0.595 \mathrm{NS}$ \\
\hline Constant & 1.349 & 0.977 & 0.175 \\
\hline
\end{tabular}

Significant at ${ }^{* * *}=1 \%$ level of significance

NS $=$ Not Significant

$\mathrm{R} 2=0.76$

\section{Constraints affecting women participation in cowpea production}

Table 4 below presents the constraints affecting women participation in cowpea production in Wammako Local Government Area of Sokoto State. The results of the finding shows that the major constraints affecting the women farmers were prevalence of pest and diseases (92.0\%), followed by high cost of pesticides and fertilizer (90.0\%), Inadequate finance (86.0\%), high cost of labour (76.0\%), high cost of farm inputs (64.0\%) inadequate land and poor storage facilities (60.0\%). Other constraints indicated by the farmers include shortage of farm inputs, low government participation, poor marketing system and pricing and low level of income. $[13,14]$ attributed the low women participation in cowpea production to lack of initial agricultural production capital, which 
acts as a barrier to women cowpea farmers and also limits their means of hired labour or affording available technology [15-62] (Table 4).

Table 4: Constraints Affecting Women Participation in Cowpea Production.

\begin{tabular}{|c|c|c|}
\hline Constraints & Frequency & Percentage \\
\hline Inadequate land & 30 & 60 \\
\hline Inadequate Finance & 43 & 86 \\
\hline $\begin{array}{l}\text { Shortage of farm } \\
\text { inputs }\end{array}$ & 24 & 48 \\
\hline $\begin{array}{l}\text { High cost of farm } \\
\text { inputs }\end{array}$ & 32 & 64 \\
\hline $\begin{array}{l}\text { High cost of pesticides } \\
\text { and fertilizers }\end{array}$ & 45 & 90 \\
\hline Low patronage & 0 & 0 \\
\hline High cost of labour & 38 & 76 \\
\hline $\begin{array}{l}\text { Low government } \\
\text { participation in } \\
\text { cowpea }\end{array}$ & 13 & 26 \\
\hline $\begin{array}{c}\text { Scarcity/shortage } \\
\text { of improved cowpea } \\
\text { variety }\end{array}$ & 0 & 0 \\
\hline $\begin{array}{l}\text { Low level of extension } \\
\text { visits }\end{array}$ & 1 & 2 \\
\hline $\begin{array}{l}\text { Lack of processing } \\
\text { facilities }\end{array}$ & 0 & 0 \\
\hline Poor storage facilities & 30 & 60 \\
\hline $\begin{array}{l}\text { Natural hazard, flood } \\
\text { and draught }\end{array}$ & 4 & 8 \\
\hline $\begin{array}{c}\text { Poor marketing } \\
\text { system a and poor } \\
\text { pricing }\end{array}$ & 3 & 6 \\
\hline $\begin{array}{c}\text { Prevalence of pest and } \\
\text { diseases }\end{array}$ & 46 & 92 \\
\hline
\end{tabular}

\section{Conclusion and Recommendations}

\section{Conclusion}

Based on the findings, the study therefore conclude that, farming and trading were the major economic activities of the women farmers in the study area and their level of income is lowmoderate and the major factors that influence their participation in cowpea production were farm size and farm distance to the nearest good road. This indicates that with adequate farmland and production inputs, they have the potential to increase their present level of output. The participation of women in cowpea production in the study area is associated with many constraints which includes high incidence of pests and diseases, high cost of pesticides and fertilizer, inadequate finance, high cost of labour and poor storage facilities.

\section{Recommendations}

Based on the findings of this study, it was recommended that:

1. The government should formulate policies to encourage women farmers in the study area to adopt and sustain the use of improved varieties of cowpea which will lead to higher yields and as result lead to higher incomes.
2. The government should provide incentives specifically to the women farmers like ready market and fixed prices for their outputs. Adequate market infrastructure and facilities should be provided to the women so that they can easily sell their increased cowpea yields.

3. Improved cowpea varieties and other inputs should be made readily available and accessible to the women farmers at affordable prices, on time and in adequate quantities

4. Pests and diseases were major problems of women cowpea farmers as such women farmers in the study area should be given adequate enlightenment on how to control them. The IITA should also improve the cowpea varieties to increase their resistance to pests and diseases.

5. Extension service should be intensified to enhance the women's knowledge

6. Pesticides and fertilizers should be subsidized to make them affordable by the farmers.

7. Land policies that deprived women access to land should be amended so that women can own farmlands as that will influences their participation in farming activities and cowpea production.

\section{Acknowledgement}

None.

\section{Conflict of Interest}

No conflict of interest.

\section{References}

1. International Institute of Tropical Africa, IITA (2014) Cowpea Project for Africa Research and Development. International Institute of Tropical Agriculture.

2. Zongoma BA (2015) Impact Assessment of Improved Cowpea Varieties on Women Farmers in Southern Part of Borno State, Nigeria. A Thesis Submitted to the School of Postgraduate Studies, University of Maiduguri.

3. Food and Agriculture Organization, FAO, (2014) Guide for Beneficiary Results Assessment of Agricultural Emergency Interventions. FAO of the United Nations, Rome, Italy.

4. Olajide AA (2011) Empirical Analysis of Agricultural Productivity Growth in Sub Saharan Africa. 1961-2003, Libyan Agricultural Research Centre Journal Int 2(5): 224-231.

5. Akepu M (2017) Women Participation in Rice Production: A case Study of Doma Local Government Area of Nasarawa State.

6. Doss C (2011) If women hold up half the sky, how much of worlds food they produce, ESA working paper No 1104.

7. Anushiya S (2013) Participation of Family-Women in Agricultural Production: A Case Study of Jaffna District, Sri Lanka. Journal of Economics and Sustainable Development 4 (13): 1-6.

8. Damisa M, Samndi R, Yohann M, (2007) Women Participation in Agricultural Production: A Probit Analysis. J Applied Sci 7: 412-416.

9. National Population Commission (2006) National Population Census Provisional Report for Nigeria: Draft Report - Sokoto State, Nigeria.

10. Akpabio IA (2005) Women and Agricultural Development: in Ike. I Agricultural Extension and Rural Sociology, SNAAP Press Ltd Enugu, Nigeria. 
11. Ekong EE (2003) An Introduction to Rural Sociology. 2nd Edition Dove Educational Publishers, Uyo, Nigeria: 204.

12. Ayoola JB (1999) Economic Analysis of Women Entrepreneurship in Low Income Households of Benue State, Nigeria. A PhD Thesis Submitted to Abubarka Tafawa Balewa University, Bauchi, Nigeria : 53-55.

13. Oladebo JO (2003) The effects of socio-economic characteristics of farmers on land degradation in the derived guinea savannah ecological zone of Nigeria. International Journal of Environmental Studies: University of Ibadan 1(1): 133-144.

14. Spore H (2003) Yield and Euglogies. Information for Agricultural Development in Africa Caribbean and Pacified Countries (ACP) No 105:

15. Abah D, Tor IE (2012) Cost and Returns of Cowpea Enterprise in Lafia Local Government of Nasarawa State, Nigeria. Production Agriculture and Technology 8(2): 59-67.

16. Aboki E, Yuguda R (2013) Determinants of Profitability in Cowpea Production in Tatum LGA of Taraba State, Nigeria. Journal of Agricultural Science 4(1): 33-37.

17. Agarwal B (2001) Participatory Exclusions, Community Forestry, and Gender: An Analysis for South Asia and a Conceptual Framework. World Development 29: 1623-1648.

18. Agness M (2010) Factors Influencing Cowpea Producers' Choice of Marketing Channels in Zambia. A Research Report Presented to the Department of Agriculture Economics and Extension Education.

19. Agricultural Development economics Division, The Food and Agriculture Organizations of the United Nations.

20. Akande $\mathrm{T}$ (2000) An overview of the Nigerian economy. Nigerian Institute of Social and Economic Research (NISER) Annual report p.47.

21. Akinnagbe OM, Ajayi AR (2010) Assessment of farmers' benefits derived from Olam organization sustainable cocoa production extension activities in Ondo State, Nigeria. Journal of Agricultural Extension 14(1): $13-24$.

22. Akpokodje G, Lancon F, Erenstain (2001) Nigerians Rice Economy: State of the art paper presented at the NISER/WARDA Nigerian Rice Economy Stakeholders Workshop, Ibadan.

23. Bakoji, I, Azare, IM, Babayo A (2017) Analysis of Cowpea Fried Paste among Women Entrepreneur in Bauchi Metropolis, Bauchi State, Nigeria. Global Journal of Agricultural Research 2: 10-16.

24. Bashir MB, Ndaghu AA, Nakwe SHG, Abdulazeez AW, Samuel RT (2018) Adoption of Cowpea Production Technologies Among Farmers in Taraba State, Nigeria. Journal of Agricultural and Veterinary Science 11(3): $37-$ 46.

25. Chamala S (1995) Overview of Participative Action Approaches in Australian land and water management. In 'Participative approaches for Land care'. Ed K Keith pp. 5-42.

26. Devas N, Grant U (2003) Local government decision-making - citizen participation and local accountability: some evidence from Kenya and Uganda. Journal of Public Administration and Development 23: 307-316.

27. Dommati D, Reddi CK (2011) Socio-Economic conditions of Agricultural Labour in Andhra Pradesh: A Case Study in Karimnagar District. International Journal of Business Economics and Management Research 2(3): 115-134.

28. Dugje IY, Omoigui, LO, Ekeleme F, Kamara AY, Ajeigbe H (2009) Farmers Guide to Cowpea Production in West Africa. IITA Ibadan, Nigeria p.20.

29. Emadi MH (2001) Women and political participation. President Center for Women Participation, Zeitoun publication, Tehran, Iran.

30. Eyben R, Ladbury S (1995) Popular Participation in Aid-assisted Projects: why more in theory than practice? In 'Power and Participatory Development'. Ed S Wright, Intermediate Technology Publications: London.

31. Ezumah N, Di Domenico CM (1995) Enhancing the Role of Women in Crop Production: A case of Igbo Women in Nigeria. World Development Report 23(10): 1731-1744.
32. Food and Agricultural Organization (2005) State of food insecurity in the world. Rome, FAO.

33. Food and Agriculture Organization (FAO) (2006). Agriculture Towards 2015/30: Technical Interim Reports on Cowpea Production and Demands in Sub - Saharan Africa 11(1): 1-3.

34. Habibi M, Zandieh M (2011). Rural women participation and Employment in Iran.

35. Helen OI (2007) Analysis of Factors Influencing Women Adoption of Improved Cassava Production and Processing. Technologies in Mopamuro Local Government Area of Kogi State: 56-57.

36. Hovio T (2007) Women's role in cowpea farming. FAO Women and population division. Rome.

37. Hussein K (1995) Participatory Ideology and Practical Development: Agency control in a fisheries project, Kariba Lake. In: Wright (Ed.) Power and Participatory Development. Intermediate Technology Publications, London, UK.

38. Kagbu JH (2016) Adoption of Recommended Cowpea Production Practices among Women Cowpea Farmers in Nasarawa State, Nigeria. Journal of Agricultural Extension 20(1): 1-14

39. Kebbeh M, Haefele S, Fagade SO (2003) Challenges and opportunities for improving irrigated cowpea productivity in Nigeria. Abidjan: WARDA.

40. Kelly D (2000) Community Participation in Rangeland Management: A report for the Rural Industries Research and Development Corporation RIRDC: Barton ACT

41. Lane J (1995) Non-governmental Organizations and Participatory Development: The concept in theory versus the concept in practice. In: S Wright (Ed.) Power and Participatory Development. Intermediate Technology Publications, London, UK.

42. Lawal JO, Oluyole KA (2008) Factors Influencing Adoption of Research Results and Agricultural Technologies Among Cocoa Farming Households in Oyo State, Nigeria. Int Journal of Sustainable Crop Production 3(5): $10-12$

43. Lyons M, Smuts C, Stephens A (2001) Participation, Empowerment and Sustainability: (how) do the links work? Urban Studies 38: 1233-1251.

44. National Agricultural Extension and Research Liaison Services (NAERLS) and Federal Department of Agricultural Extension (2014) Agricultural performance survey of 2014 wet season in Nigeria, Executive summary p.23

45. Ndekha A, Hansen E H, Molgaard P, Woelk G, Furu P (2003) Community participation as an interactive learning process: experiences from a schistosomiasis control project in Zimbabwe. Acta Tropica 85: 325-338.

46. Nelson N, Wright S (1995) Participation and Power. In: Wright S (Ed.) Power and participatory development. Intermediate Technology Publications, London, UK.

47. New World Dictionary, Second College Edition.

48. Nkonyo E, Davis K (2008) The Statistical Challenges of attributing impacts of FADAMA II Project on demand-driven advisory service program in Nigeria, Africa. Paper presented at workshop on: Rethinking Impact: Understanding the complexity of Poverty and Change, Cali Colombia pp.26-29.

49. Ogbe SE (2009) Determinant of Credit demand and microfinance Outreach to farmers in Abia State: A case study of National Special Programme on Food Security. Michael Okpara University of Agriculture Umudike p.45.

50. Ogunbameru BO, Pandey IM (1998) Nigerian rural women participation in agriculture and decision-making: Focus on Adamawa and Taraba States, Nigeria. Journal of Agricultural Extension 7: 71-76.

51. Oxford Dictionary of English Etymology.

52. Paul S (1996) Community Participation in Development Projects. World Bank, Discussion Paper No 6, Washington DC, USA.

53. Pelling M (1998) Participation, Social Capital and Vulnerability to urban flooding in Guyana. Journal of International Development 10: 469-486. 
54. Price S, Mylius B (1991) Social Analysis and Community Participation. Journal of Public Administration and Development 23: 377-379.

55. Rahman S A (2008) Women's Involvement in Agriculture in Northern and Southern Kaduna State, Nigeria. Journal of Gender Studies 17(1): 17-26.

56. Sathar Z, Kazi S (1997) Women's autonomy, livelihood and fertility: A study of rural Punjab. Publication of Pakistan Institute of Development Economics, Islamabad, Pakistan.

57. Sulo T, Koech P, Chumo C, Chepngeno W (2012) Socioeconomic Factors Affecting the Adoption of Improved Agricultural Technologies among Women in Marakwet County Kenya. Journal of Emerging Trends in Economics and Management Sciences (JETEMS) 3(4): 312-317.
58. Tikare S, Youssef D, Donnelly Roark P, Shah P (2001) Organizing participatory processes. Journal of Public Administration and Development 23: 212-216.

59. United Nations (UN) (2005) World Survey on the Role of women in Development.

60. Warner M (1997) Consensus' participation: An example for protected areas planning. Journal of Public Administration and Development 17: 413-432.

61. Wikipedia (2019) Woman.

62. World Bank (1995) Annual Report. 